\title{
Physico-Chemical Characteristics and Quality Evaluation of Malaysia Haruan (Channa striatus) and Toman (Channa micropeltes) Fish Oil: Preliminary Quality Analysis Prior to Therapeutic Consumption
}

\author{
SAIFUL IRWAN ZUBAIRI*, WINNIE NGUI SHY YI, ZALIFAH MOHD KASIM \\ and ZAINUN NURZAHIM
}

Department of Food Sciences, Faculty of Science and Technology, Universiti Kebangsaan Malaysia, 43600 UKM Bangi, Selangor, Malaysia.

${ }^{*}$ Corresponding author E-mail: saiful-z@ukm.edu.my

http://dx.doi.org/10.13005/ojc/370314

(Received: April 28, 2021; Accepted: June 14, 2021)

\begin{abstract}
The local Channa species used in this research were Channa striatus (haruan) and Channa micropeltes (toman). Both samples were extracted using soxhlet extraction to procure the fish oil and then examined on its physico-chemical properties. The $C$. micropeltes species shows the highest yield of extracted fish oil $(\%, w / w)$ with dry weight basis $(9.51 \pm 1.20 \%)$. The physico-chemical results of the fish oil from haruan and toman were as follows respectively; colour: yellowish dark red for both species, specific gravity: $0.93 \pm 0.10,0.91 \pm 0.03$; AV: $21.78 \pm 2.30 \mathrm{mg} \mathrm{KOH} / \mathrm{g}, 5.55 \pm$ $1.64 \mathrm{mg} \mathrm{KOH} / \mathrm{g} ;$ FFA: $10.95 \pm 1.16 \%, 2.79 \pm 0.83 \%$ and PV: $18.00 \pm 6.56$. meq. $/ \mathrm{kg}, 14.67 \pm 3.79$ meq. $/ \mathrm{kg}$. Both fish oils showed a relatively comparable fatty acid profile. The availability of seven major enriched fatty acid constituents in both fish oils namely dodecanoic acid, 9-hexadecenoic acid, hexadecanoic acid, linoleic acid, oleic acid, octadecanoic acid, docosahexaenoic acid and an infinitesimal amount of arachidonic acid (the main precursor for wound healing process) may perhaps be requisite for therapeutic consumption.
\end{abstract}

Keywords: Channa species, Fish oil, Physicochemical analysis, Soxhlet extract, Wound healing.

\section{INTRODUCTION}

Snakehead fish or haruan were categorized in Channa species under family of Channidae. This species are a group of freshwater and carnivorous fishes, and was very different from others due to its unique snake-head similarity shape (Mohd Husin, 2007). In fact, they had been widely found with variety of species and consumed as food in many tropical countries such as Malaysia and other Southeast Asian countries (Mat Jais, 2007; Mohd
Hasan, 2005). There is a total of 30 Channa spp. found worldwide but only 7 species are known from Malaysia. They are Channa bankanensis, Channa gachua, Channa lucius, Channa marulioides, Channa melasoma, Channa micropeltes and Channa striatus (Courtenay \& Williams, 2004) or better known as haruan hutan, haruan todak, ikan bujuk, toman bunga, haruan palas, toman batik and haruan locally. The haruan extract from $C$. striatus species are mostly used today due to its potential in tissue synthesis and help in wound healing

This is an Open Access article licensed under a Creative Commons license: Attribution 4.0 International (CC- BY). Published by Oriental Scientific Publishing Company @ 2018

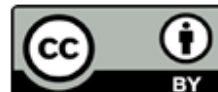


(Mudjiharto, 2007) which are potentially due to its essence concoction broth or from its fish oil. The fish oil, which is the lipid fraction extracted from fish and fish by-products are rich with important fatty acids, especially polyunsaturated fatty acids (PUFA), decosahexaenoic acid (DHA) and eicosapentaenoic acid (EPA) (Faizal et al., 2017; Kim and Mendis, 2006). The presence of certain PUFA in fish oil can be the regulators that affect the synthesis and activity of cytokines for promoting wound healing (Huang et al., 2018). For that reason, the fish oil obtained through soxhlet method from both well-known Channa sp. which are $C$. striatus (haruan) and $C$. micropeltes (toman) was analyzed for their physicochemical properties, fatty acid and its compositional profiles which could be the essential compound for therapeutic consumption mainly on wound healing.

\section{MATERIALS AND METHODS}

\section{Raw materials}

The species used in this study were Channa striatus (haruan) and Channa micropeltes (toman) that purchased from local markets in Bandar Baru Bangi and wet market Kajang, Selangor, Malaysia (Fig. 1). The fish species were then visually inspected by Malaysian Fishery Department (MFD), crossreferenced and vouched (JPM: 2002/627) for validation under the local fresh water fish species checklist.

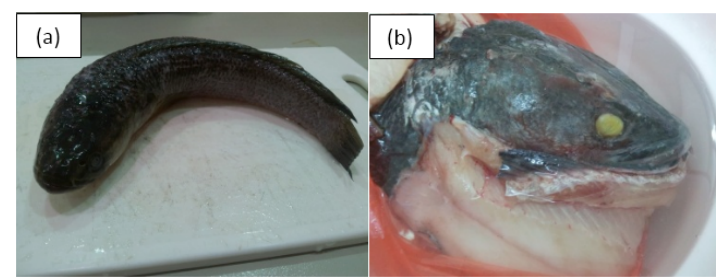

Fig. 1. Pictorial of (a) Channa striatus (haruan) and (b) Channa micropeltes (toman) confirmed and vouched by the Malaysian Fishery Department (MFD)

\section{Pre-treatment of raw material}

After collecting the fish samples, they were cleansed by discarding their bones, liver, stomach and viscera manually (Fig. 2). Only edible muscles with skin were needed prior to physico-chemical characteristic evaluation. In preparation prior to aforementioned analysis, frozen samples (frozen at $-10^{\circ} \mathrm{C}$ ) were freeze-dried $(48 \mathrm{~h})$, thawed, rinsed and cleansed with distilled water twice and air-dried at $25^{\circ} \mathrm{C}$ prior to grinding and fish oil extraction process.

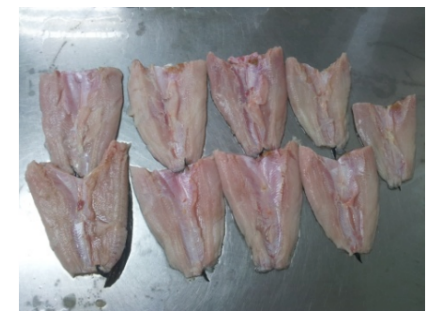

Fig. 2. Cleaned boneless fillet of (a) Channa striatus (haruan) and (b) Channa micropeltes (toman) prior to soxhlet extraction process

\section{Chemicals}

$\mathrm{N}$-hexane $\left(\right.$ Systerm ${ }^{\circledR}$, ChemAR $\left.^{\circledR}\right)$ was used as solvent to extract oil from all fish samples. Other analytical chemicals employed include hexane (LiChrosolv ${ }^{\circledR}$ ), methanol (J.T.Baker), potassium hydroxide (R\&M Chemicals), glacial acetic acid $\left(\right.$ Systerm $\left.^{\circledR}\right)$, chloroform (Systerm $\left.{ }^{\circledR}\right)$, potassium iodide (QRëC $C^{\mathrm{TM}}$ ), sodium thiosulphate (Merck KGaA), $1 \%(\mathrm{w} / \mathrm{v})$ soluble starch (Acros Organics), 95\% (v/v) ethyl alcohol neutral (HmbG ${ }^{\circledR}$ Chemicals), $1 \%(\mathrm{w} / \mathrm{v})$ phenolphthalein ( $\mathrm{HmbG}^{\circledast}$ Chemicals), sodium hydroxide (R\&M Chemicals) and carbon tetrachloride (QRëC $\left.{ }^{\mathrm{TM}}\right)$. All reagents used for the extraction and chemical analyses were of analytical grade, unless specified otherwise.

\section{Fish oil soxhlet extraction process}

The frozen boneless fish fillet was freezedried for $48 \mathrm{~h}$ beforehand and deformed by a mill grinder (Panasonic MK-5078, Japan) for 5 minutes. The soxhlet extractor and $n$-hexane as solvent were used to acquire fish oil for $2 \mathrm{~h}$ of extraction process (solvent-to-solid ratio of $1: 10 \mathrm{ml} / \mathrm{g})(\mathrm{n}=3)$. The fish oil was collected eventually and stored at $-20^{\circ} \mathrm{C}$ prior to physico-chemical analysis.

\section{Physical properties of extracted fish oil Colour analysis}

The colour of extracted fish oil was measured by using Lovibond ${ }^{\circledR}$ Tintometer Colourimeter Model $F$ (Minolta, Japan), where $L^{*}$ value indicated degree of lightness to darkness, $a^{*}$ value depicted degree of redness to greenness and $b^{*}$ value epitomized degree of yellowness to blueness. This analysis was conducted in triplicates to obtain the average of colour profiles value $(n=3)$.

\section{Fish oil specific gravity}

The specific gravity of the unrefined fish oils was determined using a $25 \mathrm{~mL}$ glass-measuring cylinder $(n=3)$ (Bako et al., 2017). The weight-tovolume ratio of oil $(\mathrm{g} / \mathrm{mL})$ was divided by the weight- 
to-volume ratio of water $(\mathrm{g} / \mathrm{mL})$ at $20 \pm 1^{\circ} \mathrm{C}$ to obtain the specific gravity. Finally, the specific gravity of fish oil was determined and calculated as density of fish oil per density of water.

\section{Chemical properties of extracted fish oil Peroxide value (PV) analysis}

The peroxide value of fish oil was examined based on the prior work of AOCS protocols (AOCS, 1998). The mixture was titrated with $0.1 \mathrm{~N}$ sodium thiosulphate solution $\left(\mathrm{Na}_{2} \mathrm{~S}_{2} \mathrm{O}_{3}\right)$ with $1 \mathrm{~mL}$ of $1 \%$ $(\mathrm{w} / \mathrm{v})$ soluble starch as indicator until blue colour disappeared in reference to blank $(n=3)$.

\section{Free fatty acid (FFA) value analysis}

The free fatty acid (FFA) value of sample was identified according to the AOCS protocols (AOCS, 1998). Approximately of $1 \%(\mathrm{w} / \mathrm{v})$ phenolphthalein was added into the mixture and titrated with $0.1 \mathrm{~N}$ sodium hydroxide $(\mathrm{NaOH})$ until pinkish color was observed $(n=3)$.

\section{Acid value (AV) determination ( $\mathrm{mg} \mathrm{KOH} / \mathrm{g}$ )}

The acid value was determined based on the prior work by Abdulkadir et al., (2010). Approximately of $1 \mathrm{~g}$ fat sample was dissolved in carbon tetrachloride $\left(\mathrm{CCl}_{4}\right)$ and titrated with 0.05 $\mathrm{M}$ alkaline, using phenolphthalein as indicator until dark colour was observed $(n=3)$.

\section{Fatty acid compositional analysis}

The fatty acid methyl esters (FAME) composition of the extracted fish oil was determined by using GC-MS (Shidmadzu QP2010 quadrupole) equipped with carbowax capillary column $(30 \mathrm{~cm} \mathrm{X}$ $0.25 \mathrm{~mm}$ internal diameter; 0.25 in film thickness) and flame-ionization detector with $2.0 \mu \mathrm{L}$ of both oils was injected into the column. Fatty acid (\%) were calculated from the proportion of each fatty acid within the sample; these percentages were used to create a fatty acid profile for each oil used $(n=3)$.

\section{Statistical analysis}

The data of the study were analyzed by using SPSS software version 20.0. One way analysis of variance (ANOVA) was used for the determination of significant differences between samples and significant probability level was set at $95 \%(p<0.05)$.

\section{RESULTS AND DISCUSSION}

\section{Fish oil extract}

Pre freeze-drying method was able to minimize sample final moisture without losing its biological activities, thus maintain high product quality (Mohammod et al., 2012). Around $39.40 \mathrm{~g}$ $(20.87 \%)$ of haruan freeze-dried filler (FDF) was obtained from $188.8 \mathrm{~g}$ wet weight of snakehead fillet after drying process, whereas for toman fish, it was $43.58 \mathrm{~g}(24.31 \%)$ FDF from $179.29 \mathrm{~g}$ wet weight of toman fillet. Haruan dan toman fish oils extracted in this study were in the form of crude fish oils. As shown in Fig. 3, it was found that haruan and toman contained lipid of $5.50 \pm 0.10 \%$ and $9.51 \pm 1.20 \%$ respectively, which is slightly higher than the prior work (Zuraini et al., 2005). The observed differences in maximum oil yield may have been due to different species, geographical regions, age and diet.

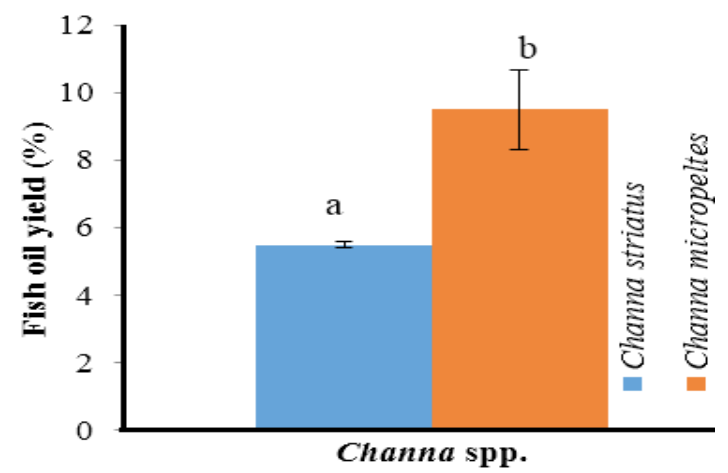

Fig. 3. Fish oil yield (\%, dry basis) of both Channa spp. extracted using soxhlet method. Results are the mean value of three replicates \pm S.D. $(n=3)$. a-b Mean with different superscript letter are significantly different $(p<0.05)$

Physical properties of extracted fish oil

Generally, it was observed that the oils extracted from two of the Channa fish species (Table 1) were tolerable to the standard values (specific gravity and peroxide value), nevertheless some were above the normal ranges (free fatty acid and acid value) (Abdulkadir and Abubakar, 2010). It was actually due to the fact that most of the standard values from the prior work results were reliant on geographical locations, seasons and intention to which the oil was produced for (Ahmed et al., 2017).

Table 1: Physico-chemical characteristics of both haruan and toman fish oils

\begin{tabular}{lcc}
\hline Physico-chemical properties & Haruan & Toman \\
\hline (a) Color Profiles: & & \\
L $^{*}$ & $22.65 \pm 0.19 \mathrm{a}$ & $26.34 \pm 1.27 \mathrm{~b}$ \\
$\mathrm{a}^{*}$ & $7.26 \pm 0.15 \mathrm{a}$ & $5.21 \pm 0.49 \mathrm{~b}$ \\
b $^{*}$ & $3.38 \pm 0.11 \mathrm{a}$ & $5.91 \pm 0.27 \mathrm{~b}$ \\
(b) Specific gravity & $0.93 \pm 0.10 \mathrm{a}$ & $0.91 \pm 0.03 \mathrm{a}$ \\
(c) Peroxide value (meq./kg) & $18.00 \pm 6.56 \mathrm{a}$ & $14.67 \pm 3.79 \mathrm{a}$ \\
(d) Free fatty acid value (\%) & $10.95 \pm 1.16 \mathrm{a}$ & $2.79 \pm 0.83 \mathrm{~b}$ \\
e) Acid value (mg KOH/g) & $21.78 \pm 2.30 \mathrm{a}$ & $5.55 \pm 1.64 \mathrm{~b}$ \\
\hline
\end{tabular}

Results are the mean values of triplicates \pm S.D $(n=3)$. a-bMean with different superscript letter are significantly different $(p<0.05)$ in between species 


\section{Colour profiles}

The average values of $L^{*}, a^{*}$ and $b^{\star}$, for both fish oil samples were shown in Table 1. Generally, they were in dark red with yellow colours. These colour parameters for haruan were significantly different $(p<0.05)$ with those of toman. Lower $L^{*}$ value was determined in haruan fish oil sample, stated the overall darker tone of haruan fish oil compared to that of toman. In spite of that, there was actually not much differences when observing the lightness of the samples. Prior works have been reported that high temperature could actually induce browning reactions that can caused a decrease in lightness value, which frequently perceived to be happen when thermal treatment executed (Leadley, 2009; Patras et al., 2009). Meanwhile, the $\mathrm{a}^{*}$ (red-green colour) and $b^{*}$ (blue-yellow colour) values also showed significant difference $(p<0.05)$ between the samples. Haruan fish oil was more red in colour $\left(\mathrm{a}^{*}{ }_{\text {haruan }}=7.26\right.$ $\left.>\mathrm{a}^{*}{ }_{\text {toman }}=5.21\right)$ but less yellowish $\left(\mathrm{b}^{*}{ }_{\text {haruan }}=3.38<\right.$ $\left.\mathrm{b}^{*}{ }_{\text {toman }}=5.91\right)$ than toman fish oil. Brighter yellow colour of haruan fish oil was an indication of sample browning, confirming the tendency observed for lightness value (Ortiz et al., 2013).

\section{Specific gravity}

From Table 1, it was calculated that there was insignificant difference between the specific gravity of haruan fish oil and toman fish oil ( $p>0.05)$. The standard specific gravity of the fish oil was in between 0.907 to 0.915 (Adeniyi and Bawa, 2006). Specific gravity value of haruan fish oil $(0.93 \pm 0.10)$ was just short of the above range. Hence, the results was in range of the prior work as to indicate the efficiency of the soxhlet extraction process and its processing parameters used (Paul et al., 2013).

\section{Chemical properties of extracted fish oil Peroxide value (PV)}

Peroxide value of an oil or fat is an indication of rancidity, which occurs by autoxidation (Lee et al., 2012). Autoxidation is the most remarkable reason which causes fish oils to deteriorate in terms of quality as volatile secondary oxidation products were produced (Venkateshwarlu et al., 2004). The unsaturated nature of lipids and strong pro-oxidative system in fish tissues could cause the lipids to oxidize during the process of processing and storing. Even very low peroxide value was detected at the early oxidation stage or during the induction period, undesirable flavors and odors emerged. Oxidation of lipids not only produced rancid odors and flavors, but also can degrade the nutritional quality and safety of food through the formation of secondary products (Pak, 2005). However, there was an insignificant difference $(p>0.05)$ of PV between haruan fish oil $(18.00 \pm 6.56 \mathrm{meq} . / \mathrm{kg})$ and toman fish oil (14.67 \pm 3.79 meq. $/ \mathrm{kg}$ ). PV values of all samples were less than 20 meq. $/ \mathrm{kg}$, within the acceptable limit. This suggested that the extracted fish oils have low rate of lipid oxidation. Low PV value was also supported by the fact at which the oils were only left for few hours before analyses. The lesser the period for the oil to be expose to the atmosphere, the slower the rate of oil oxidation (Ab Kadir et al., 2017; Adeniyi and Bawa, 2006). Moreover, the PV limit which posed by the regulatory agencies for quality and acceptability of oils for human consumption is 7-8 meq./kg (Boran et al., 2006). Fish oils in this research might not suitable for consumption purposes as they were in crude oil form which did not underwent the process of refining, bleaching and deodourizing (RBD) (Jurid et al., 2020).

\section{Free fatty acid (FFA) value}

The AV between toman and haruan fish oil was noticeably incongruent of $21.78 \pm 2.30$ and 5.55 $\pm 1.64 \mathrm{mg} \mathrm{KOH} / \mathrm{g}$ respectively (Table 1$)(p<0.05)$. In fact, both fish oils surpassed the tolerable standard value of $5 \mathrm{mg} \mathrm{KOH} / \mathrm{g}$ which demonstrated low oxidative stability (Essien et al., 2012). The tolerable oil standard values are heavily dependent on geographical locations, seasons, processing method and purpose of which the oil is used for ( $\mathrm{Ab}$ Kadir et al., 2017; Adeniyi and Bawa, 2006). For that reason, the low AV was commonly correlated with the microorganisms or biological tissues lipase activity that affect the freshness and spoilage attributes (Park, 2005). As the prepared samples were not sterilized nor prepared under aseptic micro-environment, the chances of having potential enzymatic or microorganisms adulterations during the removal of internal organs and pre-processing of carcasses for the extraction and physico-chemical analysis works was undeniable attainable (Norziah et al., 2009).

\section{Acid value (AV)}

The AV between toman and haruan fish oil was noticeably incongruent of $21.78 \pm 2.30$ and 5.55 $\pm 1.64 \mathrm{mg} \mathrm{KOH} / \mathrm{g}$ respectively (Table 1$)(p<0.05)$. In fact, both fish oils surpassed the tolerable standard value of $5 \mathrm{mg} \mathrm{KOH} / \mathrm{g}$ which demonstrated low 
oxidative stability (Essien et al., 2012). The tolerable oil standard values are heavily dependent on geographical locations, seasons, processing method and purpose of which the oil is used for (Adeniyi and Bawa, 2006). For that reason, the low AV was commonly correlated with the microorganisms or biological tissues lipase activity that affect the freshness and spoilage attributes (Boran et al., 2006). As the prepared samples were not sterilized nor prepared under aseptic micro-environment, the chances of having potential enzymatic or microorganism adulterations during the removal of internal organs and pre-processing of carcasses for the extraction and physico-chemical analysis works was undeniable attainable (Norziah et al., 2009).

\section{Fatty acid composition of fish oil}

Figure $4 \mathrm{a}$ and Figure. $4 \mathrm{~b}$ illustrated the fatty acid profiles for haruan and toman fish oils respectively. There were relatively similar fatty acid profiles for haruan and toman fish oils since they were originated from the same fish species, which is Channa species. Each with total peaks from 21-26 (haruan) and from 22-23 (toman) respectively. Table 2 revealed that the content (\%) of some seven major fatty acid compounds of toman fish oil was significantly higher than that of haruan fish oil $(p<0.05)$ except for arachidonic acid as both extracts contained miniscule amount of it ( $>0.05$ ) (Peak No. 14). The fatty acid compounds obtained for both species in this research was also higher from the prior studies (Omar et al., 2010; Muhamad and Mohamad, 2012). In fact, the fatty acid composition of the fishes were greatly influenced by food, habitat, climate and whether the fish is reared or not (Muhamad and Mohamad, 2012). In this investigation, the arachidonic acid availability in both extracts is essential as it plays an important role in wound healing a(to promote wound healing by initiating collagen synthesis and re-epithelialisation in damaged tissues) and tissue regenerative in therapeutic consumption (Haniffa et al. 2014). However, the present of arachidonic acid in both haruan and toman fish oils were infinitesimal this finding has also been reported on the previous studies due to its minute concentration and was below the GC-MS detection limit (Muhamad and Mohamad, 2012).

Table 2: Eight major fatty acids composition (\%) including arachidonic acid (wound healing precursor) of haruan and toman fish oil discovered based on chromatogram Fig. 4

\begin{tabular}{|c|c|c|c|c|c|c|c|}
\hline $\begin{array}{c}\text { Peak No. } \\
\text { Haruan }\end{array}$ & $\begin{array}{c}\text { Peak No. } \\
\text { Toman }\end{array}$ & $\begin{array}{l}\text { Compound } \\
\text { name }\end{array}$ & Symbol & $\begin{array}{l}\text { Molecular } \\
\text { weight }\end{array}$ & $\begin{array}{l}\text { Molecular } \\
\text { formula }\end{array}$ & $\begin{array}{l}\text { Haruanfish } \\
\text { oil (\%) }\end{array}$ & $\begin{array}{l}\text { Tomanfish } \\
\text { oil (\%) }\end{array}$ \\
\hline 2 & 1 & Dodecanoic acid, methyl ester & $12: 0$ & 214 & $\mathrm{C}_{13} \mathrm{H}_{20} \mathrm{O}_{2}$ & $3.62 \pm 0.11^{\mathrm{a}}$ & $5.62 \pm 0.08^{b}$ \\
\hline 4 & 3 & 9-hexadecenoic acid, methyl ester & 14:0 & 242 & & $7.88 \pm 0.13^{\mathrm{a}}$ & $6.11 \pm 0.07^{b}$ \\
\hline 5 & 4 & Hexadecanoic acid, methyl ester & 16:0 & 256 & $\mathrm{C}_{16}^{15} \mathrm{H}_{32}^{30} \mathrm{O}_{2}^{2}$ & $24.07 \pm 0.47^{\mathrm{a}}$ & $29.11 \pm 0.31^{b}$ \\
\hline 7 & 6 & $\begin{array}{l}\text { 9,12- octadecatrienoic acid, } \\
\text { methyl ester (linoleic acid) }\end{array}$ & $18: 2(n-6)$ & 268 & $\mathrm{C}_{17}^{16} \mathrm{H}_{32}^{32} \mathrm{O}_{2}^{2}$ & $0.82 \pm 0.01^{a}$ & $0.18 \pm 0.01^{\mathrm{b}}$ \\
\hline 9 & 9 & $\begin{array}{l}\text { Cis-9-octadecenoic acid, } \\
\text { methyl ester (oleic acid) }\end{array}$ & $18: 1(n-6)$ & 296 & $\mathrm{C}_{19} \mathrm{H}_{36} \mathrm{O}_{2}$ & $18.20 \pm 0.12^{\mathrm{a}}$ & $15.45 \pm 0.03^{b}$ \\
\hline 13 & 11 & Octadecanoic acid, methyl ester & 18:0 & 298 & $\mathrm{C}_{19} \mathrm{H}_{38} \mathrm{O}_{2}$ & $8.13 \pm 0.31^{\mathrm{a}}$ & $11.77 \pm 0.48^{b}$ \\
\hline 14 & 14 & $\begin{array}{l}\text { 5,8,11,14-eicosatetraenoic acid, } \\
\text { methyl ester (arachidonic acid) }\end{array}$ & $20: 4(n-6)$ & 318 & $\mathrm{C}_{21} \mathrm{H}_{34} \mathrm{O}_{2}^{2}$ & $0.16 \pm 0.01^{b}$ & $0.18 \pm 0.08^{b}$ \\
\hline 21 & 23 & $4,7,10,13,16,19$ - Docosahexaenoic acid (DHA) & $22: 6(n-3)$ & 419 & $\mathrm{C}_{23} \mathrm{H}_{36} \mathrm{O}_{2}$ & $1.52 \pm 0.12^{b}$ & $1.47 \pm 0.40^{\mathrm{b}}$ \\
\hline
\end{tabular}

Results are the mean values of duplicates \pm S.D $(n=2)$. ${ }^{a-b}$ Mean with different superscript letter are significantly different $(p<0.05)$ in between species
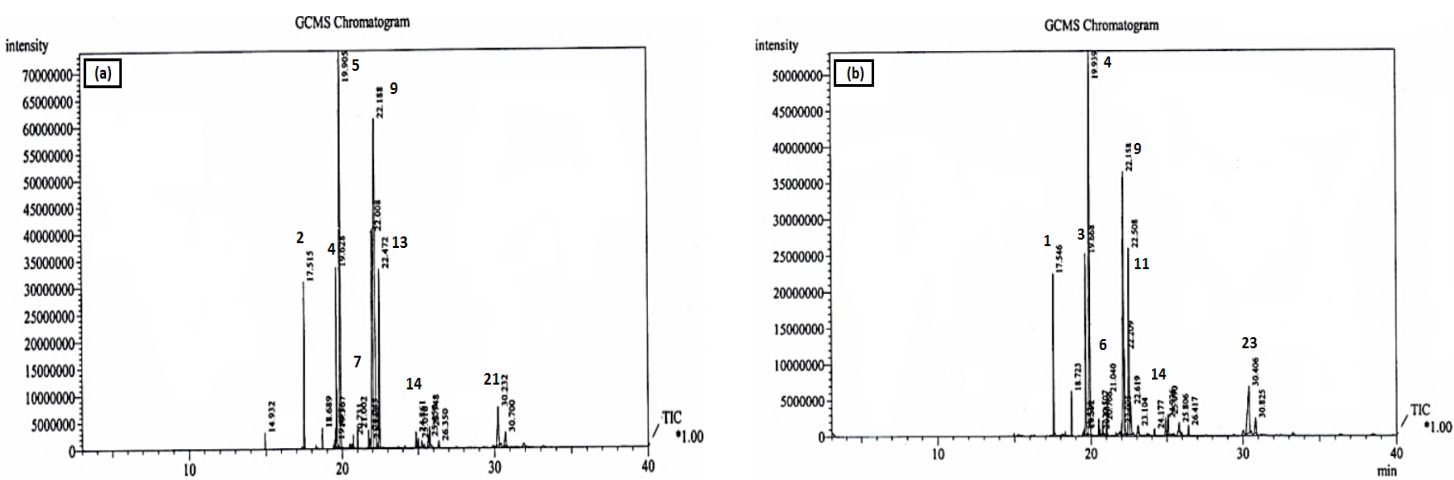

Fig. 4. GC separation of fatty acid methyl ester of (a) haruan fish oil and (b) toman fish oil with miniscule content of arachidonic acid (precursor for wound healing) and seven other major fatty acids constituents which are dodecanoic acid, 9-hexadecenoic acid, hexadecanoic acid, linoleic acid, oleic acid, octadecanoic acid and docosahexaenoic acid (numbered and circled in red) 


\section{CONCLUSION}

The soxhlet extraction yield of toman procured a higher amount of oil as compared to haruan $(p<0.05)$. Both fish oils were in the color of dark red and yellow $(p<0.05)$ with equally the same specific gravity values $(p>0.05)$. The toman fish oil was considered to be a better quality by-product than haruan fish oil as it shows lower peroxide value $(P V)$, free fatty acid (FFA) value and acid value (AV) in which signify a good and healthy nutritional content attained. The haruan and toman fish oils depicted a relatively similar fatty acid profiles. The availability of seven major fatty acid constituents which are dodecanoic acid, 9-hexadecenoic acid, hexadecanoic acid, linoleic acid, oleic acid, octadecanoic acid and docosahexaenoic acid presented in both fish oils would possibly be an essential compound for therapeutic application (e.g. wound healing) even though the arachidonic acid (the main precursor for wound healing process) was presented with an infinitesimal concentration. For that reason, it is strongly suggested that to utilize both of the aqueous and soxhlet extraction technique sequentially as to retain and optimize the availability of the arachidonic acid and other aforementioned fatty acids prior to any efficacy studies on wound healing for therapeutic consumption (e.g. 3-D biomimicry cell culture).

\section{ACKNOWLEDGEMENT}

We are grateful to Universiti Kebangsaan Malaysia (UKM) for the financial support (GUP-2018057) and the Department of Food Sciences, Faculty of Science and Technology, UKM Bangi for allowing this study to be carried out at the functional food and nutritional laboratory.

\section{Conflicts of Interest}

No data were used elsewhere to support this study and it was entirely a new set of data.

\section{REFERENCES}

1. Abdulkadir, M.; Abubakar, G. I.; Mohammed, A. Production and characterization of oil from fishes, Asia Pacific Research Network Journal of Engineering and Applied Sciences., 2010, 5(7), 1-5.

2. Ahmed, R.; Haq, M.; Cho, Y. J.; Chun, B. S. Quality Evaluation of Oil Recovered from Byproducts of Bigeye Tuna Using Supercritical Carbon Dioxide Extraction, Turkish Journal of Fisheries and Aquatic Sciences., 2017, 17, 663-672.

3. Ab Kadir, I. A.; Jurid, L. S.; Zubairi, S. I. PhysicoChemical Properties of Recycled Refined, Bleached and Deodorized (RBDPO) Palm Olein: Which Cycle Should the Olein Considered Spoilage? Jurnal Teknologi (Sciences and Engineering)., 2017, 79(4), 17-25.

4. American Oil Chemist's Society (AOCS). Official methods of analysis. United States, American Oil Chemists' society., 1998.

5. Bako, T.; Umogbai, V. I.; Awulu, J. O. Criteria for the extraction of fish oil, Agricultural Engineering International: CIGR Journal., 2017, 19(3), 120-132.

6. Boran, G.; Karacam, H.; Boran, M. Changes in the quality of fish oils due to storage temperature and time, Food Chemistry., 2006, 98(4), 693-698.

7. Bayrakli, B.; Duyar, H. A. The Effect of Raw
Material Freshness on Fish Oil Quality Produced in Fish Meal \& Oil Plant, Journal of Anatolian Envirmental and Animal Sciences., 2019, 4(3), 473-479.

8. Courtenay, W. R.; Williams, J. D. Snakeheads (Pisces, Channidae)-A Biological Synopsis and Risk Assessment, U.S: Geological Survey Circular 1251., 2004.

9. Kim, S. K.; Mendis, E. Bioactive compounds from marine processing by-products-a review, Food Research International., 2006, 39(4), 383-393.

10. Essien, E. A.; Umoren, S. A.; Essien, E. E.; Udoh, A. P. Preparation and evaluation of Cucumeropsis mannii Naud seed oil metallic soaps as driers in gloss paint, Journal of Materials and Environmental Science., 2012. 3(3), 477-484.

11. Faizal, F. F.; Ling, T. L.; Ariff Ahmad, A. A.;Zubairi, S. I. Physicochemical Characterization of Biofluid Metabolites from Liquid Residual of Tuna Fish (Euthynnus affinis) throughout Refrigerated Storage Condition. Journal of Food Quality., 2017, 2017, Article ID 4189638, 7 pages.

12. Kinyuru, J. N.; Kenji, G. M.; Simon, N.; Muhoho, M. A. Nutritional potential of longhorn grasshopper (Ruspolia differens) consumed in Siaya district, Kenya, Journal of Agricultural Science and Technology., 2010, 12, 32-46. 
13. Lee, J. H.; Asaduzzaman, A. K. M.; Yun, J. H.; Yun, J. H.; Chun, B. S. Characterization of the yellow croaker Larimichthys polyactis muscle oil extracted with supercritical carbon dioxide and an organic solvent, Fisheries and Aquatic Sciences., 2012, 15(4), 275-281.

14. Jurid, L. S.; Zubairi, S. I.; Kasim, Z. M.; Ab Kadir, I. A. The Effect of Repetitive Frying on Physicochemical Properties of Refined, Bleached and Deodorized Malaysian Tenera Palm Olein During Deep-Fat Frying. Arabian Journal of Chemistry., 2020. 13(7), 6149-6160.

15. Mohd Husin, N. Morphological and genetic variability of Malaysian Channa spp. based on morphometric and RAPD Techniques, Master of Science Thesis, Universiti Sains Malaysia., 2007.

16. Muhamad, A.; Mohamad, J. Fatty Acids Composition of Selected Malaysian Fishes, Sains Malaysiana., 2012, 41(1), 81-94.

17. Mohammod, S.; Rahman, A.; Mujumdar, A.S. Atmospheric Freeze Drying, Progress in Food Preservation., 2012, 144-160.

18. Mat Jais, A. M. Pharmacognosy and pharmacology of Haruan (Channa striatus), a medicinal fish with wound healing properties, Latin American and Caribbean Bulletin of Medicinal and Aromatic Plants., 2007, 6(3), 52-60.

19. Mohd Hasan, S. Anti-inflammatory and antinociceptive properties of three local Channa species crude extracts, Master of Science Thesis, School of Graduate Studies, Universiti Putra Malaysia., 2005.

20. Molla, A. H.; Saha, C.; Ahsan, M. S.; Talukder, S. M.; Alam, M.T. Physico-chemical and microbiological investigation of the lipid from Bangladeshi fresh water fish Mystus vittatus, Rajshahi University Zoological Society., 2007, 26, 21-25.

21. Mudjiharto. Fish as human serum albumin substitute, http://www.prasetya.brawijaya. ac.id. 2007, Accessed on 18th August 2020.

22. Norziah, M. H.; Nuraini, J.; Lee, K. Y. Studies on the extraction and characterization of fish oil from wastes of seafood processing industry. Asian Journal of Food and AgroIndustry., 2009, 2(4), 959-973.

23. Omar, M. N.; Md. Yusoff, N. S. A.; Zainuddin, N. A.; Yunus, K. $\omega$-Fatty acids from Malaysian giant snakehead (Channa micropeltes) fish oil, Orient. J. Chem., 2010, 26(1), 1-4.

24. Ortiz, J.; Lemus-Mondaca, R.; VegaGálvez, A.; Ah-Hen, K.; Puente-Diaz, L.; Zura-Bravo, L.; Aubourg, S. Influence of airdrying temperature on drying kinetics, color, firmness and biochemical characteristics of Atlantic salmon (Salmo salar L.) fillets. Food Chemistry., 2013, 139(1), 162-169.

25. Paul, D. K.; Islam, R.; Sattar, M. A. Physicochemical studies of lipids and nutrient contents of Channa striatus and Channa marulius. Turkish Journal of Fisheries and Aquatic Sciences., 2013, 13(3), 487-493.

26. Patras, A.; Tiwari, B. K.; Brunton, N. P.; Butler, $F$. Modelling the effect of different sterilisation treatments on antioxidant activity and colour of carrot slices during storage. Food Chemistry., 2009, 114(2), 484-491.

27. Pak, C. S. Stability and quality of fish oil during typical domestic application, PhD Thesis, Wonsan University of Fisheries., 2005.

28. Venkateshwarlu, G.; Let, M. B.; Meyer, A. S.; Jacobsen, $C$. Chemical and olfactometric characterization of volatile flavor compounds in a fish oil enriched milk emulsion. Journal of Agricultural and Food Chemistry., 2004, 52(2), 311-317.

29. Zuraini, A.; Somchit, M. N.; Solihah, M. H.; Goh, Y. M.; Arifah, A. K.; Zakaria, M. S.; Somchit, N.; Rajion, M. A.; Zakaria, Z. A.; Mat Jais, A. M. Fatty acid and amino acid composition of three local Malaysian Channa spp. Fish. Food Chemistry., 2006, 97(4), 674-678. 